\title{
MONOGRAFIE/MONOGRAPH
}

Valérie Tothová, Věra Hellerová (eds) (2021). Využití měřicích nástrojů v ošetřovatelství [Use of measuring instruments in nursing]. Praha. NLN, s. r. o. 225 s. ISBN 978-80-7422-817-9. DOI: 10.32725/zsf.2021.74228179

\section{Využití hodnoticích a měřicích nástrojů u pacientů s tělesným znevýhodněním} kap. 4: 10.32725/zsf.2021.74228179.02

\section{Jan Neugebauer}

University of South Bohemia in České Budějovice, Faculty of Health and Social Sciences, Institute of Nursing, Midwifery and Emergency Care, České Budějovice, Czech Republic

\section{Souhrn}

Tělesné znevýhodnění je multifaktoriálním fenoménem prolínajícím mnoho vědních oborů. $V$ české klinické praxi se ošetřovatelství zaměřuje na holisticko-humanistický přístup, a proto je potřeba hodnotit tuto problematiku komplexně. Vzhledem k nejasnosti terminologie je potřeba si uvědomit rozdílnost mezi poškozením (impairment), postižením (handicap) a znevýhodněním (disability). Samotné hodnocení by se poté mělo odvíjet od oblastí, které jsou poškozeny, postiženy nebo znevýhodněny.

V klinické praxi se využívá mnoho standardizovaných nástrojů pro hodnocení aktuálního zdravotního stavu a rizik vznikajících $v$ důsledku reverzibilního $\mathrm{i}$ ireverzibilního tělesného znevýhodnění. Jako nejvíce rozšířené standardizované nástroje pro účely hodnocení rizik se v klinické praxi využívají Norton scale, Braden scale pro hodnocení rizika vzniku dekubitů; Morse Fall Scale, Tinetti test a Conley scale pro hodnocení rizika pádu; Barthel test a IADL pro hodnocení soběstačnosti. $V$ zahraniční literatuře i klinické praxi je doporučováno využít nástroje pro hodnocení znevýhodnění (WHODAS 2.0, MDS), které poskytují nejen pohled na znevýhodněné oblasti, ale i na úroveň znevýhodnění.

Výsledky naší studie prokázaly souvislost mezi vzděláním sester, používáním hodnoticích nástrojů, edukací sester $v$ klinické praxi a doporučením nástrojů pro hodnocení pacientů s tělesným znevýhodněním v celé ČR. Sestry s vysokoškolským vzděláním pracují více se standardizovanými hodnoticími nástroji a doporučují je pro klinickou praxi, podobně i sestry, které prošly edukací o problematice tělesného znevýhodnění. Sestry se středoškolským vzděláním používají pouze nástroje, které jsou nařízené managementem zdravotnického zařízení jako povinná součást dokumentace.

Klíčová slova: hodnoticí nástroje, měřici nástroje, pacient, tělesné znevýhodnění, vzdělání sester

\section{Podkapitoly:}

4.1 Filozofie a pochopení pojmu tělesné znevýhodnění

4.1.1 Vývoj terminologie

4.1.2 Klasifikace tělesného znevýhodnění

4.2 Hodnocení potřeb u pacientů s tělesným znevýhodněním

4.2.1 Hodnocení pacientů s tělesným znevýhodněním v souvislosti se vzděláním sester

4.2.2 Hodnocení soběstačnosti 
4.2.3 Hodnocení rizika pádu

4.2.4 Hodnocení rizika vzniku dekubitů

4.2.5 Hodnocení znevýhodnění

4.2.6 Sebehodnocení pacientů s tělesným znevýhodněním

4.3 Postoj sester k pacientům s tělesným znevýhodněním

4.3.1 Poskytovaná péče pacientům $s$ tělesným znevýhodněním v klinické praxi

4.3.2 Edukace pacientů s tělesným znevýhodněním

4.3.3 Edukace osob pečujících o pacienty s tělesným znevýhodněním

4.4 Edukace sester o problematice tělesného znevýhodnění

4.5 Souvislosti s používáním nástrojů v klinické praxi

\section{Literatura}

1. Almeida, L. R. S., et al. (2015). Disability is an Independent Predictor of Falls and Recurrent Falls in People with Parkinson's Disease Without a History of Falls: A One-Year Prospective Study. J Parkins Dis 5(4): 855-864. DOI: 10.3233/JPD-150651.

2. Aloweni, F., et al. (2018). A prediction tool for hospital-acquired pressure ulcers among surgical patients: Surgical pressure ulcer risk score. Int Wound J 16(1): 164-175. DOI: 10.1111/iwj.13007.

3. Anastasiou, D., Kauffman, J. M. (2013). The Social Model of Disability: Dichotomy between Impairment and Disability. J Med Philos 38(4): 441-459. DOI: 10.1093/jmp/jht026.

4. Appelgren, M., et al. (2018). Nurses' experiences of caring for patients with intellectual developmental disorders: a systematic review using a meta-ethnographic approach. BMC Nursing 17: 51. DOI: 10.1186/s12912-018-0316-9.

5. Aranda-Gallardo, M., et al. (2013). Instruments for assessing the risk of falls in acute hospitalized patients: a systematic review protocol. J Adv Nurs 69(1): 185-193. DOI: 10.1111/j.13652648.2012.06104.x.

6. Aronovitch, S. A., et al. (1992). Investigation of the Knoll Assessment Scale in a tertiary care facility. Decubitus 5(3): 70-72.

7. Artico, M., et al. (2017). Prevalence, incidence and associated factors of pressure ulcers in home palliative care patients: A retrospective chart review. Palliat Med 32(1): 299-307. DOI: $10.1177 / 0269216317737671$.

8. Ayello, E. A., Braden, B. (2002). How and Why to Do Pressure Ulcer Risk Assessment. Adv Skin Wound Care 15(3): 125-131. DOI: 10.1097/00129334-200205000-00008.

9. Baart, J., et al. (2020). Quality of Life of Persons with Disabilities in Southern Nations, Nationalities, and Peoples' Region, Ethiopia. Disability, CBR \& Inclusive Development 30(3): 5-18. DOI: 10.5463/DCID.V30I3.879.

10. Baek, S., et al. (2014). Validity of the Morse Fall Scale implemented in an electronic medical record system. J Clin Nurs 23(17-18): 2434-2440. DOI: 10.1111/jocn.12359.

11. Bahadori, M., et al. (2016). The barriers to the application of the research findings from the nurses' perspective: A case study in a teaching hospital. J Educ Health Promot 5: 14. DOI: 10.4103/22779531.184553.

12. Bachani, A. M., et al. (2014). A new screening instrument for disability in low-income and middleincome settings: application at the Iganga-Mayuge Demographic Surveillance System (IM-DSS), Uganda. BMJ Open 4(12): e005795. DOI: 10.1136/bmjopen-2014-005795.

13. Bickenbach, J., et al. (2012). ICF CORE SETS Manual for Clinical Practice. Nottwil: Switzerland.

14. Bogart, K. R. (2014). The role of disability self-concept in adaptation to congenital or acquired disability. Rehabil Psychol 59(1): 107-115. DOI: 10.1037/a0035800. 
15. Bóriková, I., et al. (2018). The risk of falling among older adults in long-term care: screening by Morse Fall Scale. Kontakt 20(2): e111-e119. DOI: 10.1016/j.kontakt.2017.11.006.

16. Boyles, C. M., et al. (2008). Representation of disability in nursing and healthcare literature: an integrative review. J Adv Nurs 62(4): 428-437. DOI: 10.1111/j.1365-2648.2008.04623.x.

17. Braden, B., Bergstrom, N. (1987). Conceptual schema for the study of the etiology of pressure sores. Rehabil Nurs 12(1): 8-12. DOI: 10.1002/j.2048-7940.1987.tb00541.x.

18. Brienza, D., et al. (2018). Predictors of pressure ulcer incidence following traumatic spinal cord injury: a secondary analysis of a prospective longitudinal study. Spinal Cord 56(1): 28-34. DOI: 10.1038/sc.2017.96.

19. Brynes, N., et al. (2017). Improvement of Patient- and Family-Specific Care for Children with Special Behavioral Needs in the Emergency Setting: A Behavioral Needs Education. J Emerg Nurs 43(3): 202207. DOI: 10.1016/j.jen.2016.07.010.

20. Carlozzi, N. E., et al. (2015). Validity of the 12-item World Health Organization Disability Assessment Schedule 2.0 (WHODAS 2.0) in individuals with Huntington disease (HD). Qual Life Res 24(1): 19631971. DOI: 10.1007/s11136-015-0930-x.

21. Carvalho-Pinto, B. P. B., Faria, C. D. C. M. (2016). Health, function and disability in stroke patients in the community. Braz J Phys Ther 20(4). DOI: 10.1590/bjpt-rbf.2014.0171.

22. Cichosz, S. L., et al. (2019). Prediction of In-Hospital Pressure Ulcer Development. Adv Wound Care 8(1): 1-6. DOI: 10.1089/wound.2018.0803.

23. Clasper, J., Ramasamy, A. (2013). Traumatic amputations. Br J Pain 7(2): 67-73. DOI: $10.1177 / 2049463713487324$.

24. Conley, D., et al. (1999). The challenge of predicting patients at risk for falling: development of the Conley Scale. Medsurg Nurs 8(6): 348-354.

25. Corrado, B., et al. (2020). Evidence-Based Practice in Rehabilitation of Myasthenia Gravis. A Systematic Review of the Literature. J Funct Morphol Kinesiol 5(4): 71. DOI: 10.3390/jfmk5040071.

26. Cullati, S., et al. (2019). When Team Conflicts Threaten Quality of Care: A Study of Health Care Professionals' Experiences and Perceptions. Mayo Clin Proc Innov Qual Outcomes 3(1): 43-51. DOI: 10.1016/j.mayocpiqo.2018.11.003.

27. Curcio, F., et al. (2016). Tinetti mobility test is related to muscle mass and strength in noninstitutionalized elderly people. Age (Dordr) 38(5-6): 525-533. DOI: 10.1007/s11357-016-9935-9.

28. Curley, M. A. Q., et al. (2018). Predicting Pressure Injury Risk in Pediatric Patients: The Braden QD Scale. J Periatr 192: 189-195.e2. DOI: 10.1016/j.jpeds.2017.09.045.

29. Davis, K. L., Davis, D. D. (2020). Disability Determination And Impairment Rating. StatPearls: StatPearls Publishing.

30. de Azevedo Macena, M. S., et al. (2017). Pressure Ulcer Risk Evaluation in Critical Patients: Clinical and Social Characteristics. Open Nurs J 11: 91-97. DOI: 10.2174/1874434601711010091.

31. De Beaudrap, P., et al. (2017). Prevalence of HIV infection among people with disabilities: a population-based observational study in Yaoundé, Cameroon (HandiVIH). Lancet HIV 4(4): e161-e168. DOI: 10.1016/S2352-3018(16)30209-0.

32. de Gouveia Santos, V. L. C., et al. (2018). Risk Assessment in Pressure Ulcers, s. 57-77. In: Romanelli, M., et al. Science and Practice of Pressure Ulcer Management. London: Springer. DOI: 10.1007/978-14471-7413-4_5.

33. DeSilva, M., et al. (2016). Congenital anomalies: Case definition and guidelines for data collection, analysis, and presentation of immunization safety data. Vaccine 34(49): 6015-6025. DOI: 10.1016/j.vaccine.2016.03.047.

34. Ehrmann, C., et al. (2018). Describing Functioning in People Living With Spinal Cord Injury in Switzerland: A Graphical Modeling Approach. Arch Phys Med Rehabil 99(10): 1965-1981. DOI: 10.1016/j.apmr.2018.04.015. 
35. Fässberg, M. M., et al. (2016). A systematic review of physical illness, functional disability, and suicidal behaviour among older adults. Aging Ment Health 20(2): 166-194. DOI:

10.1080/13607863.2015.1083945.

36. Fazel, F. S., et al. (2018). Predictive Value of Braden Risk Factors in Pressure Ulcers of Outpatients With Spinal Cord Injury. Acta Med Iran 56(1): 56-61.

37. Fernández-López, J. A., et al. (2010). Quality of life, health and well-being conceptualizations from the perspective of the International Classification of Functioning, disability and health (ICF). Rev Esp Salud Pública 84(2): 169-184. DOI: 10.1590/s1135-57272010000200005.

38. Fiatarone, M. A., Evans, W. J. (1993). The Etiology and Reversibility of Muscle Dysfunction in the Aged. J Gerontol 48(Special Issue): 77-83. DOI: 10.1093/geronj/48.special_issue.77.

39. Forjuoh, S. (2001). Injury prevention in people with disabilities. BMJ 322(7292): 940-941. DOI: 10.1136/bmj.322.7292.940.

40. Gabriel, S., et al. (2019). Prevalence and associated factors of intertrigo in aged nursing home residents: a multi-center cross-sectional prevalence study. BMC Geriatr 19(1): 105. DOI:

10.1186/s12877-019-1100-8.

41. Gažiová, M. (2013). Jednotný postup proti dekubitom. Sestra 12(1-2): 12-14.

42. GBD 2017 Disease and Injury Incidence and Prevalence Collaborators (2018). Global, regional, and national incidence, prevalence, and years lived with disability for 354 diseases and injuries for 195 countries and territories, 1990-2017: a systematic analysis for the Global Burden of Disease Study 2017. Lancet 392(10159): 1789-1858. DOI: 10.1016/S0140-6736(18)32279-7.

43. Goering, S. (2015). Rethinking disability: the social model of disability and chronic disease. Curr Rev Musculoskelet Med 8(2): 134-138. DOI: 10.1007/s12178-015-9273-z.

44. Gould, L. J., et al. (2019). Pressure ulcer summit 2018: An interdisciplinary approach to improve our understanding of the risk of pressure-induced tissue damage. Wound Repair Regen 27(5): 497-508. DOI: 10.1111/wrr.12730.

45. Grigorian, A., et al. (2018). Pressure Ulcer in Trauma Patients: A Higher Spinal Cord Injury Level Leads to Higher Risk. J Am Coll Clin Wound Spec 9(1-3): 24-31.e1. DOI: 10.1016/j.jccw.2018.06.001.

46. Griswold, L. H., et al. (2017). Validity of the Braden Scale in grading pressure ulcers in trauma and burn patients. J Surg Res 219: 151-157. DOI: 10.1016/j.jss.2017.05.095.

47. Gulley, S. P., et al. (2018). At the intersection of chronic disease, disability and health services research: A scoping literature review. Disab Health J 11(2): 192-203. DOI: 10.1016/j.dhjo.2017.12.012.

48. Haladová, E., Nechvátalová, L. (2010). Vyšetřovací metody hybného systému. Brno: Národní centrum ošetřovatelství a nelékařských zdravotnických oborů, $135 \mathrm{~s}$.

49. Hansen, A. E., Marcus, N. J. (2018). How and why Hans Kraus, MD, helped President Kennedy's back pain. J Neurosurg Spine 28(6): 688-689. DOI: 10.3171/2017.9.SPINE17838.

50. Hardiker, N. R., et al. (2000). Standards for nursing terminology. J Am Med Inform Assoc 7(6): 523528. DOI: 10.1136/jamia.2000.0070523.

51. Hopkins, R. O., et al. (2017). Instrumental Activities of Daily Living after Critical Illness: A Systematic Review. Ann Am Thor Soc 14(8): 1332-1343. DOI: 10.1513/AnnalsATS.201701-059SR.

52. Hum, A. M., Premasari, A. A. (2020). Handicap and Disability: What is the Difference? IJLIT 3(1): 163167.

53. Chang, K.-H., et al. (2015). Association between muscle power impairment and WHODAS 2.0 in older adults with physical disability in Taiwan. Disabil Rehabil 37(8): 712-720. DOI: 10.3109/09638288.2014.940428.

54. Charalambous, C., et al. (2018). Evaluation of the Validity and Reliability of the Waterlow Pressure Ulcer Risk Assessment Scale. Med Arch 72(2): 141-144. DOI: 10.5455/medarh.2018.72.141-144.

55. Cheung, M. K. T., et al. (2015). Validation of the World Health Organization Assessment Schedule II Chinese Traditional Version (WHODAS II CT) in persons with disabilities and chronic illnesses for Chinese population. Disabil Rehabil 37(20): 1902-1907. DOI: 10.3109/09638288.2014.989336. 
56. Chow, S. K. Y., et al. (2007). Evaluation of the Morse Fall Scale: Applicability in Chinese hospital populations. Int J Nurs Stud 44(4).: 556-565. DOI: 10.1016/j.ijnurstu.2005.12.003.

57. Ireland, P., Johnston, L. M. (2012). Measures of Self-Care Independence for Children with Osteochondrodysplasia: A Clinimetric Review. Phys Occup Ther Pediatr 32(1): 80-96. DOI: 10.3109/01942638.2011.593619.

58. Jablensky, A. (2009). Handicap and Disability: words versus concepts. Disability and Rehabilitation, 22(11): 513-514. DOI: 10.1080/096382800414023.

59. Jasemi, M., et al. (2017). A concept analysis of holistic care by hybrid model. Indian Palliat Care 23(1): 71-80. DOI: 10.4103/0973-1075.197960.

60. Jaul, E., et al. (2018). An overview of co-morbidities and the development of pressure ulcers among older adults. BMC Geriatrics, 18(1).

61. Jehu, D., et al. (2020). Risk factors for recurrent falls in older adults: a study protocol for a systematic review with meta-analysis. BMJ Open 10(5): e033602. DOI: 10.1136/bmjopen-2019-033602.

62. Kalligerou, F., et al. (2020). Assessing functional status using the IADL-extended scale: results from the HELIAD study. Int Psychogeriatr 32(4): 541. DOI: 10.1017/S1041610219001558.

63. Kalter, H. (1998). Misused terminology. Reprod Toxicol 12(4): 496-498. DOI: 10.1016/s08906238(98)00029-x.

64. Keller, P. B., et al. (2002). Pressure ulcers in intensive care patients: a review of risks and prevention. Intensive Care Medicine 28(10). 1379-1388. DOI: 10.1007/s00134-002-1487-z.

65. Kendíková, J., Vosmik, M. (2013). Jak zvládnout problémy dětí se školou? Praha: Pasparta, $112 \mathrm{~s}$.

66. Kertay, L. (2019). Administrative Issues and Perspective: Impairment Ratings and Disability Determinations. Phys Med Rehabil Clin N Am 30(3): 499-509. DOI: 10.1016/j.pmr.2019.03.001.

67. Klimetti, M., et al. (2008). Tension neck and evaluation of a physical training course among office workers in a bank corporation. J Adv Nurs 26(5): 962-967. DOI: 10.1046/j.1365-2648.1997.00390.x.

68. Koenders, N., et al. (2019). Exploring barriers to physical activity of patients at the internal medicine and surgical wards: a retrospective analysis of continuously collected data. Disabil Rehabil 1-7. DOI: 10.1080/09638288.2019.1685013.

69. Köpke, S., Meyer, G. (2006). The Tinetti test: Babylon in geriatric assessment. Z Gerontol Geriatr 39(4): 288-291. DOI: 10.1007/s00391-006-0398-y.

70. Kraus, J., et al. (2014). Léze mozkových nervů u dětí. Periatr praxi 15(1): 31-34.

71. Krawczyk, P., et al. (2016). Ortoticko-protetické léčení tělesně postižených dětí - komplexní péče. Pohybové ústrojí 23(1): 49-80.

72. Krishnan, S., et al. (2017). Association between presence of pneumonia and pressure ulcer formation following traumatic spinal cord injury. J Spinal Cord Med 40(4): 415-422. DOI: 10.1080/10790268.2016.1180099.

73. Kuvalekar, K., et al. (2015). Quality of Life among Persons with Physical Disability in Udupi Taluk: A Cross Sectional Study. J Family Med Prim Care 4(1): 69-73. DOI: 10.4103/2249-4863.152258.

74. Larsson, I. E., et al. (2011). Patients' perceptions of barriers for participation in nursing care. Scand J Caring Sci 25(3): 575-582. DOI: 10.1111/j.1471-6712.2010.00866.x.

75. Lewis, G. M., et al. (2012). Pressure ulcers and risk assessment in severe burns. J Burn Care Res 33(5): 619-623. DOI: 10.1097/BCR.0b013e31825d5538.

76. Li, D., et al. (2018). Reliability and validity Munro Scale on the assessment. Int J Clin Exp Med 11(9): 9811-9818.

77. Liddiard, K. (2013). The work of disabled identities in intimate relationships. Disability \& Society 29(1): 115-128. DOI: 10.1080/09687599.2013.776486.

78. Lima-Serrano, M., et al. (2018). Predictive validity and reliability of the Braden scale for risk assessment of pressure ulcers in an intensive care unit. Med Intensiva (Engl Ed) 42(2): 82-91. DOI: 10.1016/j.medin.2016.12.014. 
79. Lisowska, B. (2017). How to measure disability: survey usability versus usefulness. Development initiatives. Development Initiatives Poverty Research. [online] [cit. 2021-01-22]. Dostupné z: https://devinit.org/blog/measure-disability-survey-usability-versus-usefulness/

80. Liu, W., et al. (2015). Optimizing Eating Performance for Long-Term Care Residents With Dementia: Testing the Impact of Function-Focused Care for Cognitively Impaired. J Am Med Dir Assoc 16(12): 1062-1068. DOI: 10.1016/j.jamda.2015.06.023.

81. Loeb, M. (2016). Development of Disability Measures for Surveys: The Washington Group Extended Set on Functioning. International Measurement of Disability, pp. 97-122. DOI: 10.1007/978-3-31928498-9_7.

82. López, M., et al. (2018). Relationship between pressure ulcer risk based on Norton Scale and on the “Eating/Drinking" need assessment. J Nurs Manag 27(1): 117-124. DOI: 10.1111/jonm.12655.

83. López-Entrambasaguas, O. M., et al. (2019). Newly Qualified Nurses' Perception of Their Competency Achievement on Leaving University: A Qualitative Study. Int J Environ Res Public Health 16(21): 4284. DOI: $10.3390 /$ ijerph16214284.

84. Lovallo, C., et al. (2010). Accidental falls in hospital inpatients: evaluation of sensitivity and specificity of two risk assessment tools. J Adv Nurs 66(3): 690-696. DOI: 10.1111/j.1365-2648.2009.05231.x.

85. Lu, S.J., et al. (2019). Determinants of Employment Outcome for the People with Schizophrenia Using the WHODAS 2.0. J Occup Rehabil 29(2): 375-383. DOI: 10.1007/s10926-018-9794-6.

86. Mactaggart, I., et al. (2017). A population-based survey of visual impairment and its correlates in Mahabubnagar district, Telangana State, India. Ophthalmic Epidemiol 25(3): 238-245. DOI: 10.1080/09286586.2017.1418386.

87. Madans, J. H. (2016). The Washington Group's Contribution to Disability Statistics and a Look to the Future. Cham: Springer International Publishing.

88. Mahalingam, S., et al. (2014). Improving pressure ulcer risk assessment and management using the Waterlow scale at a London teaching hospital. J Wound Care 23(12): 613-622. DOI: 10.12968/jowc.2014.23.12.613.

89. Maich, K., Sider, S. (2019). Special Education Needs and Disabilities in Secondary Education (Canada), s. 1. Bloomsury Publishing. DOI: 10.5040/9781474209441.0054.

90. Mallah, Z., et al. (2015). The Effectiveness of a Pressure Ulcer Intervention Program on the Prevalence of Hospital Acquired Pressure Ulcers: Controlled Before and After Study. Appl Nurs Res 28(2): 106113. DOI: 10.1016/j.apnr.2014.07.001.

91. Maritz, R., et al. (2017). The International Classification of Functioning, Disability and Health (ICF) in Electronic Health Records. Appl Clin Inform 8(3): 964-980. DOI: 10.4338/ACI2017050078.

92. Maruyama, K., et al. (2010). Bone fracture in physically disabled children attending schools for handicapped children in Japan. Environ Health Prev Med 15(3): 135-140. DOI: 10.1007/s12199-0090121-x.

93. Mayoral, A. P. (2019). The use of Barthel index for the assessment of the functional recovery after osteoporotic hip fracture: One year follow-up. PloS One 14(2): e0212000. DOI: 10.1371/journal.pone.0212000.

94. McCord, S., et al. (2004). Risk factors associated with pressure ulcers in the pediatric intensive care unit. J Wound Ostomy Continence Nurs 31(4): 179-183. DOI: 10.1097/00152192-200407000-00005.

95. McNamara, J. K., et al. (2011). A longitudinal study of kindergarten children at risk for reading disabilities: the poor really are getting poorer. J Learn Disabil 44(5): 421-430. DOI: 10.1177/0022219411410040.

96. Mikula, J., Müllerová, M. (2008). Prevence dekubitů, Praha: Grada, 96 s.

97. Miller, K. (2016). Summary of Washington Group Question Evaluation Studies. International Measurement of Disability 61: 69-84.

98. MKN-10 - Mezinárorní statistická klasifikace nemocí a přidružených zdravotních problémů (2008). Ústav zdravotnických informací a statistiky České republiky. Praha: Bomtom Agency. 
99. Mlinac, M. E., Feng, M. C. (2016). Assessment of Activities of Daily Living, Self-Care, and Independence. Arch Clin Neuropsychol 31(6): 506-516. DOI: 10.1093/arclin/acw049.

100. Moen, V. P., et al. (2017). Validation of World Health Organization Assessment Schedule 2.0 in specialized somatic rehabilitation services in Norway. Qual Life Res 26(2): 505-514. DOI: 10.1007/s11136-016-1384-5.

101. Molton, I. R., Yorkston, K. M. (2017). Growing Older With a Physical Disability: A Special Application of the Successful Aging Paradigm. J Gerontol B Psychol Sci Soc Sci 72(2): 290-299. DOI: 10.1093/geronb/gbw122.

102. Moore, Z. E. H., Cowman, S. (2014). Risk assessment tools for the prevention of pressure ulcers. Cochrane Database Syst Rev (2): CD006471. DOI: 10.1002/14651858.CD006471.pub3.

103. Moore, Z. E. H., Patton, D. (2019). Risk assessment tools for the prevention of pressure ulcers. Cochrane Database Syst Rev 2019(1): CD006471. DOI: 10.1002/14651858.CD006471.pub4.

104. Mörchen, M., et al. (2019). Disability-Disaggregated Data Collection: Hospital-Based Application of the Washington Group Questions in an Eye Hospital in Paraguay. Int J Environ Res Public Health 16(17): 3085. DOI: 10.3390/ijerph16173085.

105. Morse, J. M. (2009). Preventing patient falls: establishing a fall intervention program. New York: Springer Pub. Co.

106. Morse, J. M., et al. (1989). A prospective study to identify the fall-prone patient. Soc Sci Med 28(1): 81-86.

107. MPSV ČR (2020). Úmluva OSN o právech osob se zdravotním postižením. Ministerstvo práce a sociálních věcí. [online] [cit. 2020-01-05]. Dostupné z: https://www.mpsv.cz/umluva-osn-o-pravechosob-se-zdravotnim-postizenim

108. Müller, O. (Ed.) a kol. (2014). Terapie ve speciální pedagogice. 2., přeprac. vyd., Praha: Grada, 512 s. 109. Nazarko, L. (2018). Prevention of pressure ulcers in community care settings. Independent Nurse 7. DOI: 10.12968/indn.2018.7.24.

110. Neugebauer, J., Bártlová, S. (2019). Existuje stigmatizace v ošetřovatelské profesi? Kontakt 21(3): 263268. DOI: 10.32725/kont.2019.037.

111. Neugebauer, J., Tóthová, V. (2019). Physical disabilities in nursing - the use of selected tools to monitor physically disabled patients' needs. Kontakt 21(4): 344-351. DOI: 10.32725/kont.2019.032.

112. Neugebauer, J., Tóthová, V. (2020). Assessment of pressure ulcers in physically handicapped patients. Developments in Health Sciences.

113. Neugebauer, J., et al. (2021a) Postoj sester k pacientům s tělesným znevýhodněním. Zdravotnícke listy [v tisku].

114. Neugebauer, J., et al. (2021b) Pressure Ulcer Assessment: Relationship between Education and Use of the Standardized Tools. J Nurs Scholars [v recenzním řízení].

115. Neugebauer, J., et al. (2021c). Use of Standardized and Non-Standardized Tools for Measuring the Risk of Falls and Independence in Clinical Practice. Int J Environ Res Public Health 18(6): 3226. DOI: 10.3390/ijerph18063226.

116. Neugebauer, J., et al. (2021d) Sebereflexe potřeb pacientů s tělesným znevýhodněním v průběhu hospitalizace. Praktický lékař 101(1): 17-20.

117. Neugebauer, J., et al. (2021e). Vnímání svého zdraví - pohled pacientů s tělesným znevýhodněním. Logos Polytechnikos [v recenzním řízení].

118. Neugebauer, J., et al. (2021f). Hodnocení vybraných aspektů pacienty s tělesným znevýhodněním. Logos Polytechnikos 12(1): 75-85.

119. Neugebauer, J., et al. (2021g). Vnímání potřeb pacienty s tělesným znevýhodněním. In: Sborník abstraktů: VII. ročník Studentské vědecké konference. České Budějovice: Jihočeská univerzita v Českých Budějovicích, Zdravotně sociální fakulta.

120. Ningsih, W., et al. (2018). Self-Care Training Improves the Attitudes and Skills of Caregivers for Children with Physical Disability. J Ners 13(1): 9-17. DOI: 10.20473/jn.v13i1.5613. 
121. Noh, J.-W., et al. (2016). Relationship between Physical Disability and Depression by Gender: A Panel Regression Model. PloS One 11(11): e0166238. DOI: 10.1371/journal.pone.0166238.

122. Novosad, L. (2011). Tělesné postižení jako fenomén i životní realita: diskurzivní pohledy na tělo, tělesnost, pohyb, člověka a tělesné postižení. Praha: Portál, $166 \mathrm{~s}$.

123. O'Brien, G., et al. (2018). The relationship between nurses assessment of early pressure ulcer damage and sub epidermal moisture measurement: A prospective explorative study. J Tissue Viability 27(4): 232-237. DOI: 10.1016/j.jtv.2018.06.004.

124. O'Connell, B., Myers, H. (2002). The sensitivity and specificity of the Morse Fall Scale in an acute care setting. J Clin Nurs 11(1): 134-136. DOI: 10.1046/j.1365-2702.2002.00578.x.

125. Ong, S. R., et al. (2018). Physical activity, visual impairment, and eye disease. Eye 32(8): 1296-1303. DOI: 1038/s41433-018-0081-8.

126. Ovayolu, O. U., et al. (2012). The relationship between self-care agency, disability levels and factors regarding these situations among patients with rheumatoid arthritis. J Clin Nurs 21(1-2): 101-110. DOI: 10.1111/j.1365-2702.2011.03710.x.

127. Palese, A., et al. (2016). Post-hoc validation of the Conley Scale in predicting the risk of falling with older in-hospital medical patients: findings from a multicentre longitudinal study. Aging Clin Exp Res 28(1): 139-146. DOI: 10.1007/s40520-015-0378-4.

128. Pancorbo-Hidalgo, P. L., et al. (2018). Prevalence of pressure injuries and other dependence-related skin lesions among paediatric patients in hospitals in Spain. EWMA Journal 19(2): 29-37.

129. Parveen, H., Noohu, M. M. (2017). Evaluation of psychometric properties of Tinetti performanceoriented mobility assessment scale in subjects with knee osteoarthritis. Hong Kong Physiother J 36: 25-32. DOI: 10.1016/j.hkpj.2016.07.001.

130. Peacock, G., et al. (2015). Health Care for Americans with Disabilities - 25 Years after the ADA. N Engl J Med 373(10): 892-893. DOI: 10.1056/NEJMp1508854.

131. Pellicciari, L., et al. (2019). A Rasch analysis of the Conley Scale in patients admitted to a general hospital. Disabil Rehabil 41(23): 2807-2816. DOI: 10.1080/09638288.2018.1478000.

132. Perera, N., Agboola, S. (2019). Are formal self-care interventions for healthy people effective? A systematic review of the evidence. BMJ Glob Health 4(Suppl. 10): e001415. DOI: 10.1136/bmjgh-2019001415

133. Perkins, Z. B., et al. (2012). Factors affecting outcome after traumatic limb amputation. The Br J Surg 99(Suppl. 1): 75-86. DOI: 10.1002/bjs.7766.

134. Persson, M., et al. (2017). Risk of major congenital malformations in relation to maternal overweight and obesity severity: cohort study of 1.2 million singletons. BMJ Clin Res 375: 2563. DOI: 10.1136/bmj.j2563.

135. Porcel-Gálvez, A. M., et al. (2018). Psychometric Testing of INTEGRARE, an Instrument for the Assesment of Pressure Ulcer Risk in Inpatients. Int J Nurs Knowl 29(3): 165-170. DOI: 10.1111/20473095.12173.

136. Preskitt, J. K., et al. (2013). Underinsurance in children with special health care needs: the impact of definition on findings. Matern Child Health J 17(8): 1478-1487. DOI: 10.1007/s10995-012-1155-z.

137. Rabinovitz, E., et al. (2016). Norton scale for predicting prognosis in elderly patients undergoing transcatheter aortic valve implantation: A historical prospective study. J Cardiol 67(6): 519-525. DOI: 10.1016/j.jjcc.2016.01.017.

138. Rajati, F., et al. (2018). Quality of life predictors in physically disabled people. J Educ Health Promot 7: 61. DOI: 10.4103/jehp.jehp_115_17.

139. Rivolta, M. W., et al. (2019). Evaluation of the Tinetti score and fall risk assessment via accelerometrybased movement analysis. Artif Intell Med 95: 38-47. DOI: 10.1016/j.artmed.2018.08.005.

140. Rondinelli, R. D., Eskay-Auerbach, M. (2019). Medical Impairment, Disability Evaluation, and Associated Medicolegal Issues. Phys Med Rehabil Clin N Am 30(3): xv-xvi. DOI: 10.1016/j.pmr.2019.05.001. 
141. Sabariego, C. (2017). The role of the World Bank and WHO Model Disability Survey in public health. Public Health Forum 25(4): 262-264. DOI: 10.1515/pubhef-2017-0039.

142. Salmond, S. W., Echevarria, M. (2017). Healthcare Transformation and Changing Roles for Nursing. Orthop Nurs 36(1): 12-25. DOI: 10.1097/NOR.0000000000000308.

143. Sampson, E. L., et al. (2017). Living and dying with advanced dementia: A prospective cohort study of symptoms, service use and care at the end of life. Palliat Med 32(3): 668-681. DOI: 10.1177/0269216317726443.

144. Sancher-Ferreira, M., et al. (2018). Conditions for Implementing the ICF-CY in Education: The Experience in Portugal. Frontiers in Education 3(20). DOI: 10.3389/feduc.2018.00020.

145. Sardo, P. M., et al. (2016). Fall risk assessment: retrospective analysis of Morse Fall Scale scores in Portuguese hospitalized adult patients. Appl Nurs Res 31: 34-40. DOI: 10.1016/j.apnr.2015.11.013.

146. Sayar, S., et al. (2009). Incidence of pressure ulcers in intensive care unit patients at risk according to the Waterlow scale and factors influencing the development of pressure ulcers. J Clin Nurs 18(5): 765774. DOI: 10.1111/j.1365-2702.2008.02598.x.

147. Shannon, R. J., et al. (2012). Pressure Ulcer Prevention Program Study: a randomized, controlled prospective comparative value evaluation of 2 pressure ulcer prevention strategies in nursing and rehabilitation centers. Adv Skin Wound Care 25(10): 450-464. DOI:

10.1097/01.ASW.0000421461.21773.32.

148. Schneider, M., et al. (2009). Measuring disability in censuses: The case of South Africa [Mesurer le handicap dans les recensements: le cas de l'Afrique du Sud]. Alter 3(3): 245-265. DOI: 10.1016/j.alter.2009.04.002.

149. Schuntermann, M. F. (1996). The international classification of impairments, disabilities and handicaps (ICIDH) results and problems. Int J Rehabil Res 19(1): 1-11. DOI: 10.1097/00004356-19960300000001.

150. Simo Fotso, A., et al. (2019). A comparative analysis of disability measures in Cameroonian surveys. Popul Health Metr 7: 16. DOI: 10.1186/s12963-019-0198-4.

151. Skogestad, I. J., et al. (2017). Supplementing the Braden scale for pressure ulcer risk among medical inpatients: the contribution of self-reported symptoms and standard laboratory tests. J Clin Nurs 26(12): 202-214. DOI: 10.1111/jocn.13438.

152. Sloman, A., Margaretha, M. (2018). The Washington Group Short Set of Questions on Disability in Disaster Risk Reduction and humanitarian action: Lessons from practice. Int J Disaster Risk Reduct 31(1): 995-1003. DOI: 10.1016/j.ijdrr.2018.08.011.

153. Smith, S. K., et al. (2018). Evaluation of a multifactorial approach to reduce the prevalence of pressure injuries in regional Australian acute inpatient care settings. Int Wound J 15(1): 95-105. DOI: 10.1111/iwj.12840.

154. Soanes, C. (2003). The Compact Oxford English Dictionary of Current English. Oxford: University Press.

155. Sprunt, B., et al. (2019). The UNICEF/Washington Group Child Functioning Module-Accuracy, InterRater Reliability and Cut-Off Level for Disability Disaggregation of Fiji's Education Management Information System. Int J Environ Res Public Health 16(5): 806. DOI: 10.3390/ijerph16050806.

156. Stavsky, M., et al. (2017). Cerebral Palsy-Trends in Epidemiology and Recent Development in Prenatal Mechanisms of Disease, Treatment, and Prevention. Front Pediatr 5: 21. DOI: 10.3389/fped.2017.00021.

157. Sturgill, B., et al. (2019). Braden score may be associated with time to onset of catheter-associated urinary tract infection in high-risk patients: Lessons learned from a root cause analysis tool. Am J Infect Control 47(3): 343-345. DOI: 10.1016/j.ajic.2018.09.002.

158. Suprani, R., Taglioni, M. (2014). [Scale Mosaic: Definition and Testing of a Tool for Assessing the Risk of Falling and the Care Planning During Hospitalization]. Prof Inferm 67(2): 95-105. DOI: 10.7429/pi.2014.672095.

159. Šáteková, L., Žiaková, K. (2016). Inter-rater Reliability of Items of the Braden Scale, the Norton scale and Waterlow Scale. Profese Online 9(2): 10-15. DOI: 10.5507/pol.2016.007. 
160. Šáteková, L., et al. (2015). Predictive validity of the Braden scale, Norton scale and Waterlow scale in Slovak Republic. Cent Eur J Nurs Midwifery 6(3): 283-290. DOI: 10.15452/CEJNM.2015.06.0017.

161. Šáteková, L., et al. (2017). Predictive validity of the Braden Scale, Norton Scale, and Waterlow Scale in the Czech Republic. Int J Nurs Pract 23(1): e12499. DOI: 10.1111/ijn.12499.

162. Tanimura, C., et al. (2017). Self-care agency, lifestyle, and physical condition predict future frailty in community-dwelling older people. Nurs Health Sci 20(1): 31-38. DOI: 10.1111/nhs.12376.

163. Tatli, H. U., et al. (2019). Validation and application of the international classification of functioning, core set for spinal cord injury in the Turkish patients. Turk J Phys Med Rehabil 65(3): 244-258. DOI: 10.5606/tftrd.2019.3045.

164. Teng, S.-W., et al. (2013). Evolution of system for disability assessment based on the International Classification of Functioning, Disability, and Health: A Taiwanese study. J Formos Med Assoc 112(11): 691-698. DOI: 10.1016/j.jfma.2013.09.007.

165. Thomas, H., et al. (2018). Definition of whole person care in general practice in the English language literature: a systematic review. BMJ Open, 8(12): e023758. DOI: 10.1136/bmjopen-2018-023758.

166. Tinetti, M. E. (2003). Clinical Practice. Preventing Falls in Elderly Persons. N Engl J Med 348(1): 42-49. DOI: $10.1056 /$ NEJMcp020719.

167. Tinetti, M. E., et al. (1995). Risk Factors for Serious Injury During Falls by Older Persons in the Community. J Am Geriatr Soc 43(11): 1241-1221. DOI: 10.1111/j.1532-5415.1995.tb07396.x.

168. Tomata, Y., et al. (2014). Impact of the 2011 Great East Japan Earthquake and Tsunami on functional disability among older people: a longitudinal comparison of disability prevalence among Japanese municipalities. J Epidemiol Community Health 68(6): 530-533. DOI: 10.1136/jech-2013-203541.

169. Tomlinson, S. (2015). Is a sociology of special and inclusive education possible? Educ Rev 67(3): 1-9. DOI: 10.1080/00131911.2015.1021764.

170. Topinková, E. (2005). Geriatrie pro praxi. Praha: Galén, 270 s.

171. Towey, A. P., Erland, S. M. (1988). Validity and reliability of an assessment tool for pressure ulcer risk. Decubitus 1(2): 40-48.

172. Trani, J.-F., et al. (2015). Development and Validation of the 34-Item Disability Screening Questionnaire (DSQ-34) for Use in Low and Middle Income Countries Epidemiological and Development Surveys. PloS One 10(12): e0143610. DOI: 10.1371/journal.pone.0143610.

173. Tucha, O. (2017). Supporting patients with ADHD: Missed opportunities? Atten Defic Hyperact Disord 9(2): 69-71. DOI: 10.1007/s12402-017-0233-x.

174. UNTC (2020). Convention of the Rights of Persons with Disabilities. United Nations Treaty Collection. [online] [cit. 2021-01-22]. Dostupné z: https://treaties.un.org/Pages/showDetails.aspx?objid=080000028017bf87\&clang=_en

175. Urbanetto, J. S., et al. (2017). Analysis of risk prediction capability and validity of Morse Fall Scale Brazilian version. Rev Gaucha Enferm 37(4): e62200. DOI: 10.1590/1983-1447.2016.04.62200.

176. Ustün, T. B., et al. (2010). Developing the World Health Organization Disability Assessment Schedule 2.0. Bull World Health Organ 88(11): 815-823. DOI: 10.2471/BLT.09.067231.

177. Van Oyen, H., et al. (2018). Measuring disability: a systematic review of the validity and reliability of the Global Activity Limitations Indicator (GALI). Arch Public Health 76(1): 25. DOI: 10.1186/s13690018-0270-8.

178. Vanleit, B. (2009). Using the ICF to address needs of people with disabilities in international development: Cambodian case study. Disabil Rehabil 30(12-13): 991-998. DOI: 10.1080/09638280701800251.

179. Vítková, M., a kol. (1998). Integrativní speciální pedagogika. Brno: Paido, $181 \mathrm{~s}$.

180. Wall, J., Colley, T. (2003). Preventing pressure ulcers among wheelchair users: preliminary comments on the development of a self-administered risk assessment. J Tissue Viability 13(2): 48-50, 52-54. DOI: 10.1016/s0965-206x(03)80035-9. 
181. WB - Washington Group on Disability Statistics (2021). Published Materials. Washington Group on Disability Statistics. University College London. [online] [cit. 2021-01-22]. Dostupné z: https://www.washingtongroup-disability.com/resources/published-materials/

182. Wawrzyniak, K. M., et al. (2019). The World Health Organization Disability Assessment Schedule-2.0 (WHODAS 2.0) in a chronic pain population being considered for chronic opioid therapy. J Pain Res, 12: 18755-1862. DOI: 10.2147/JPR.S207870.

183. WHO (1980). International classification of impairments, disabilities, and handicaps: a manual of classification relating to the consequences of disease. New York: WHO Publication Centre USA.

184. WHO (2001). International Classification of Functioning, Disability and Health. World Health Organization. [online] [cit. 2021-01-16]. Dostupné z: https://www.who.int/classifications/international-classification-of-functioning-disability-and-health

185. WHO (2020). Model Disability Survey- Frequently Asked Question. World Health Organization. [online] [cit. 2021-01-05]. Dostupné z: https://www.who.int/disabilities/data/mds-faqs/en/

186. WHO and WB (2017). Model Disability Suvey: Providing evidence for accountability and decisionmaking. World Health Organization. [online] [cit. 2021-01-22]. Dostupné z: https://www.who.int/disabilities/data/mds.pdf

187. Wilkin, D. (2016). Caring for the Mentally Handicapped Child. New York: Taylor \& Francis Group, 224 p. DOI: $10.4324 / 9781315647869$.

188. Zákon č. 561/2004 Sb., o předškolním, základním, středním, vyšším odborném a jiném vzdělávání (školský zákon). In: Sbírka zákonů České republiky, částka 190/2004. 